\title{
FOKUS: MIGRASJONSKRISEN
}

\section{Som man sår? Om forholdet mellom vestlige intervensjoner og flyktningkrisen}

Cecilie Hellestveit ${ }^{\star}$, PhD, Seniorforsker, International Law and Policy Institute

\section{Innledning}

I 2015 søkte 1255600 flyktninger om beskyttelse i EU for første gang, ifølge tall fra Eurostat. Over halvparten hadde opprinnelse i Syria (362 800), Afghanistan (178 200) eller Irak (121500) (Eurostat 2016). Felles for disse tre statene er at alle har vært gjenstand for vestlige militære intervensjoner eller vestlig-støttede forsøk på regimeendring gjennom maktbruk de siste 15 år. Tilsvarende skjebne har også rammet Libya, som i 2010 huset mellom 1 og 2 millioner ikke-libyere hvor mange ble anslått å være i transitt fra Afrika til Europa (Di Bartolomeo 2011). Stater som Vesten har blandet seg inn i de siste 15 år er altså opphavsland eller transittland for brorparten av flyktningene til Europa. Kan årsakene og omfanget av migrasjonskrisen i Europa egentlig føres tilbake til vestlige militære intervensjoner i Afghanistan, Irak, Libya, og innblanding i Syria? Menneskene som søker tilflukt kunne da mer presist bli omtalt som «regimeendringsflyktninger» - de som forlater ruinene etter halsbrekkende forsøk fra Vesten på å innføre nye regimer og skape ny orden i skyggen av Karakush, i Saharas randsone og i Mesopotamia. Har vi oss selv å takke?

De neste sidene reflekterer rundt sannhetsgehalten i den nagende fornemmelsen av at vestlige militære intervensjoner og forsøk på regimeendringer i muslimske land siden 2001 langt på vei kan forklare migrasjonen mot Europa. Tre argumenter for en slik sammenheng presenteres og analyseres.

\section{Preludium}

Vestlig politikk i Europas randsone-land mot sør og sør-øst etter den kalde krigen har i stor grad vært styrt av vestlige egeninteresser. På 2000-tallet har vestlige land direkte eller indirekte besørget regime-endring i utvalgte land i det muslimske beltet mot sør, med klare sikkerhetspolitiske fordeler for Vesten.

^Korrespondanse: Cecilie Hellestveit, International Law and Policy Institute. Email: cecilie.hel lestveit@ilpi.org 
Den kalde krigen endte med at Sovjetunionen trakk seg ut av Midtøsten. Direkte militær inngripen i Afghanistan ble avsluttet, og russernes afghanske allierte ble overlatt til en borgerkrig som raste frem til Taliban kom på banen og raskt erobret store deler av landet i 1996. I Midtøsten trakk Sovjetunionen tilbake rundhåndede avtaler med allierte regimer, men tette bånd ble opprettholdt mellom Russland og regimene $\mathrm{i}$ Libya og Syria. Amerikanerne hadde kommet til den arabiske halvøy etter den iranske revolusjonen i 1979, men opplevde stadig større avhengighet av oljen fra Midtøsten. Behovet toppet seg i 1986, og i 1990 rykket USA inn med hele sin militærmaskin for å drive Saddam Hussein ut fra okkupasjon av Kuwait (sine oljebrønner) (Khadduri og Ghareeb 1997). Da krigen var over ble imidlertid USAs militære stående i SaudiArabia, Kuwait og Bahrain. Vantro amerikanske soldater på hellig muslimsk jord i Saudi Arabia for å støtte en uhellig allianse mellom USA og monarkier i Gulfen! Det var særlig dette som motiverte saudiarabiske Osama bin Laden til å erklære krig mot USA i 1996 (Bergen 2006). Bin Laden selv hadde slått seg opp gjennom et amerikanskstøttet saudiarabisk nettverk av jihadister i Sentral-Asia på 1980-tallet som hadde kjempet mot vantro sovjetiske styrker i Afghanistan. Etter at mujahedin hadde «vunnet» krigen mot russerne i Afghanistan, hadde imidlertid oppdragsgiverne plutselig endret spillereglene.

For en ny æra var kommet. Demokrati og menneskerettigheter hadde seiret i den Kalde Krigen, og nå var det dette som skulle dominere den ganske klode. Masseødeleggelsesvåpen skulle derimot bort.

\section{Ondskapens alkse}

Det overordnede argumentet for en sammenheng mellom vestlige intervensjoner og flyktningkrisen er at de bakenforliggende motivene for innblanding fra vestlig side har vært å styrke vestlige sikkerhetsinteresser i snever forstand. Intervensjoner av hensyn til vår egen sikkerhet har medvirket til å legge statsapparatene i et knippe land i ruiner, noe som har svekket sikkerheten til befolkningen i disse landene.

For i Midtøsten fikk masseødeleggelsesvåpen tvert imot ny giv etter 1990. Israels «kjernefysiske tvetydighet» hadde gjort at Egypt, Syria og Libya holdt seg med fattigmanns utgave av atomvåpen - kjemiske og biologiske våpen. Egypt hadde sågar brukt dem i sin krig i Jemen på 1960-tallet. Da 1990-tallet kom med nedrustningstiltak for kjemiske våpen, valgte Egypt, Libya og Syria å stå utenfor. Motivet var å bevare terrorbalansen med Israel. Kravet fra disse statene var at avrustning i Midtøsten måtte gjelde alle former for masseødeleggelsesvåpen, altså inkludert Israels antatte atomvåpen.

Også Irak og Iran hadde utviklet og benyttet masseødeleggelsesvåpen i stor skala under Iran-Irak-krigen på 1980-tallet. Det neste tiåret deltok Iran og Irak i juridiske rammeverk som forbød biologiske og kjemiske våpen, men det hersket sterk tvil om hvorvidt de faktisk overholdt sine forpliktelser. Forholdet mellom Iran og Syria ble tettere, og det ble klart at Syrias masseødeleggelsesvåpen også tjente som Irans førstelinje-forsvar mot et mulig israelsk angrep på Iran. Midt i spindelveven av masseødeleggelsesvåpen i Midtøsten sto altså Israel. På 1990-tallet lå derfor 
nøkkelen til å fjerne masseødeleggelsesvåpen i Midtøsten ganske enkelt i fred med Israel. Gjentatte forsøk til tross, det kom som kjent aldri helt i mål (Ross 2004).

Så slo Bin Laden til. Etter angrepene mot USA i 2001 ble internasjonal terrorisme flyttet oppover på listen over vestlige lands prioriteringer i Midtøsten. Amerikanerne gikk inn i Afghanistan for å uskadeliggjøre al-Qaida. De satte seg også som mål å frigjøre Afghanistan fra Taliban, som på det tidspunktet kontrollerte $95 \%$ av territoriet. Slik skulle man hindre Afghanistan fra atter å bli en frihavn for internasjonale terrororganisasjoner. Talibanregimet ble sett på som en indirekte trussel mot vestlige land, og måtte bort. Nå var det USA og dets allierte sin tur å forsøke å temme Afghanistan.

Evnen og viljen til ødeleggelse som internasjonale terrorister hadde vist gjennom 9/11 brakte opp spørsmålet om kobling mellom terrorister og masseødeleggelsesvåpen. Sikkerhetstrusselen mot vestlige land lå særlig i kombinasjonen internasjonale terrorister og masseødeleggelsesvåpen hos regimer som kunne gå i ledtog med terrorister. I 2002, like etter at Taliban var blitt drevet ut av Afghanistans hovedstad av en koalisjon av amerikanske styrker og afghanske krigsherrer, holdt George W. Bush en State of the Union-tale hvor han meislet ut sin sikkerhetsdoktrine for det nye årtusen (Bush 2002). Regimer som kunne representere en trussel mot USA og allierte som følge av en kombinasjon av fiendtlighet (eller ledtog med terrorister) og befatning med masseødeleggelsesvåpen sto på en ondskapens akse, og skulle uskadeliggiøres. Den amerikanske administrasjonen identifiserte et knippe land med regimer som var omfattet. Det gjaldt Irak, Libya, Syria, Iran og Nord-Korea (Bolton 2002). 15 år senere har Nord-Korea for lengst skaffet atomvåpen. Iran er på vei inn i varmen etter en avtale fra 2015 som holder landets atomprogram i sjakk. Regimene i Irak, Libya og Syria har derimot gått en ublid skjebne imøte.

Iraks Baath-regime ble fjernet av en amerikansk-britisk militær invasjon i 2003 under henvisning til farene for masseødeleggelsesvåpen. Saddam Hussein ble henrettet av det nye regimet i 2006, ikke for bruk av masseødeleggelsesvåpen, men for forbrytelser begått mot sjia-muslimene i Irak da Saddam fortsatt var amerikanernes mann. Påstandene om masseødeleggelsesvåpen i 2003 baserte seg på indisier som ikke holdt vann. Da amerikanerne kom tilbake for andre gang i 2014 (denne gang for å hindre ISIL i å begå folkemord) ble det imidlertid kjent at amerikanerne hadde klart å lokalisere rundt 5000 kjemiske stridshoder i Irak (NYT 2014).

Libyas Muammar Gaddafi så tegningen, og la sitt våpenprogram på hyllen i 2004, året etter at Saddam Hussein ble fjernet. Gaddafi kom deretter inn i varmen i vestlige kretser. Regimets skjebne ble imidlertid forseglet med den arabiske vår. En NATOledet luftmakt-operasjon hjalp ulike libyske grupper med å erobre Tripoli i 2011 . Operasjonen hadde mandat fra FNs Sikkerhetsråd for å håndheve flyforbudssone og våpenembargo, samt «beskytte sivile» i Libya. Gaddafi ble tatt til fange og henrettet av sine egne. Selv om operasjonen ikke handlet om masseødeleggelsesvåpen, identifiserte det nye regimet ytterligere 2 tonn kjemiske våpen som Gaddafi hadde gjemt unna, masseødeleggelsesvåpen som ble destruert i 2014 og 2016 (OPCW 2014).

En tilsvarende «libysk» prosess for regime-endring ble mobilisert for Syria, men kom aldri i mål. Sikkerhetsrådet autoriserte ikke maktbruk mot det syriske regimet, og den væpnede kampen mot det syriske regimet måtte derfor i stedet føres av syriske 
grupper med penger og våpenstøtte utenfra, samt fremmedkrigere som «kom til Syria for å sloss fordi våre regjeringer ikke kommer», slik en fremmedkriger formulerte det tidlig i 2013. Etter hvert ble kampen til en uthalingskrig som har avstedkommet en rekke utilsiktede effekter, deriblant ISIL, og har brakt regimet i Damaskus ned i knestående. Da masseødeleggelsesvåpen ble benyttet i et omfattende angrep i Damaskus i 2013, noe Obama-administrasjonen hadde definert som en «rød linje», resulterte det $i k k e$ i rask regimeendring med full amerikansk styrke. I stedet gikk USA sammen med Russland for i fellesskap å avvæpne Syrias kjemivåpenarsenal gjennom en Sikkerhetsrådsledet prosess. Regimet besto og krigen fortsatte, men masseødeleggelsesvåpnene til Syria (og Iran) som kunne utgjøre en fare for Vesten (og Russland), ble tilintetgjort.

I 2016 er status at potensielt fiendtlige regimer i Midtøsten har blitt fjernet og deres masseødeleggelsesvåpen-arsenal langt på vei destruert, uten å gå via en krevende fred med Israel. Et avgjørende bakenforliggende motiv har vært sikkerhet for vestlige land. Prisen har imidlertid vært at relativt stabile regimer har forsvunnet og at deres statsapparater har desintegrert. Vestlige land har nøytralisert en potensiell fare for oss og dermed styrket vår egen sikkerhet. Sikkerheten i landene hvor vi har intervenert har derimot blitt så dårlig at mange etter hvert ikke ser andre muligheter enn å forlate disse landene.

\section{Guardians of the Realm}

Det neste argumentet for en sammenheng mellom flyktningkrisen og intervensjoner ligger $\mathrm{i}$ at vestlige land har sviktet på et helt vesentlig punkt. Vi har ikke maktet å etablere stabile og effektive sikkerhetsstrukturer i land hvor vi har intervenert. Sikkerhetsapparater med tilstrekkelig støtte, legitimitet og kompetanse er ikke bare egnet til å håndtere sikkerhetsproblemer og sørge for orden og stabilitet. De bidrar også til å hindre at det skapes nye flyktninger, og de er viktige bestanddeler for å forvalte migranter i transitt.

For Afghanistan og Irak innebar vestlig intervensjon at sikkerhetsapparatet ble oppløst, og nye strukturer skulle etableres fra bunn. Sikkerhetsapparatet var også nøkkelen til regime-endringene i Libya og Syria. Svært ulike utfordringer har oppstått i disse landene. Felles for alle har imidlertid vært elendige sluttresultater. Statsmaktens voldsmonopol, dens evne til å besørge sikkerhet for egne innbyggere og å hindre migranter på gjennomfart har blitt betydelig svekket i kjølvannet av vestlige intervensjoner i samtlige land.

Afghanistan hadde 20 år med okkupasjon og borgerkrig bak seg i 2001. Noe sikkerhetsapparat i vestlig forstand fantes ikke, og måtte bygges fra bunnen. Vestlige soldater skulle krige mot al-Qaida og andre potensielle terrortrusler (OEF), holde opprørsbevegelsen Taliban som vi hadde drevet fra makten i sjakk med en FN- styrke (ISAF), og sist men ikke minst, hjelpe afghanske myndigheter med å bygge en stabil og legitim statsmakt. Terrorbekjempelse, opprørsbekjempelse og fredsbygging i ett og samme løft! Taliban, som særlig har støtte hos Afghanistans store etniske majoritet pashtunerne, fikk ikke være med. Afghanske krigsherrer i opposisjon til Taliban var 
våre allierte. De ble tildelt amnesti, og fikk nøkkelroller i det nye sikkerhetsapparatet. Hovedbyggeklossene i det nye «legitime» sikkerhetsapparatet besto altså av noen av de mest notoriske krigsforbryterne fra siste halvdel av det 20 århundre. Mange av våre allierte var gode venner av nabolandet Iran, som USA hadde plassert midt i ondskapens akse i 2002. Antallet vestlige soldater var svært begrenset sett i forhold til oppgavenes omfang, og sikkerhetskontraktører fra alle verdenshjørner kom etter hvert inn for å ta del i jobben og få sin del av pengesekken. Med utvalgte afghanske krigsherrer (men ikke Taliban) og kontraktører fra den ganske verden skulle landet bygges! Forestillingen ble omtrent så makaber som rollelisten skulle tilsi.

I Irak fantes derimot et sikkerhetsapparat. Det valgte imidlertid amerikanerne å oppløse da Bagdad falt. Amerikanerne skulle renske ut Saddams lojale og allierte i statsapparatet. Irak hadde jo vært en ett-parti stat, hvor alle statsansatte av betydning måtte ha tilknytning til Saddams Baath-parti. Resultatet ble at hele statsapparatet i det som var en rimelig moderne stat ble oppløst. Ca. 1,6 millioner irakere mistet sin hovedinntekt (ICG 2003:13). Da amerikanerne innså at det var umulig å bygge det nye Irak uten irakerne, ble visse irakere invitert inn igjen i varmen. Det varte imidlertid kun frem til USA overlot styringen til irakerne selv i 2004. Det nye regimet besto av irakere med mye å hevne overfor baatistene, og mange som hadde sittet i styre og stell røk ut for andre gang. Oppløsningen av sikkerhetsapparatet hadde kastet Irak inn i et voldelig inferno der den sterkestes rett gjaldt. Sikkerhetsapparatet som ble stablet på bena var i økende grad knyttet til politiske grupperinger på sjia-muslimsk side. Og bak enhver vellykket irakisk politiker i det nye demokratiet, sto etter hvert en milits med det man kan kalle evne til å sette seg i respekt (Dodge 2005).

Krigen i Irak hadde færre allierte enn USA hadde kalkulert med, ble mer militært krevende enn antatt, og krigens popularitet i USA sank snart i takt med at antallet døde soldater steg. Dette ble de private kontraktørenes store gjennombrudd. Under invasjonen i 2003 var forholdet sikkerhetskontraktører-militære 1:10. I 2007 var forholdet i Irak nærmere 1:1 (Singer 2007). Irak var et land hvor sikkerhetsapparatet hadde stått bak overgrep og internasjonale forbrytelser. Menneskerettigheter og ny legitimitet skulle innføres - om nødvendig med hard hånd. Nye strukturer skulle etableres og holdes i sjakk ved hjelp av serbere, sør-afrikanere, colombianske og russiske leiesoldater, med fingeren på avtrykkerknappen og ingen å stå til ansvar for. Med tortur skulle tortur fordrives! Dette var en modell mange irakere raskt betakket seg. USA ødela Iraks statsbærende institusjoner med makt, men ble så diskreditert i prosessen at amerikanerne ikke lenger evnet å gjenoppbygge noe i ruinene.

Vestlig inngripen i Libya gikk aldri så langt. Libyas sikkerhetsapparat var bygget for $i k k e$ å representere en trussel mot Gaddafi, som nettopp selv var en militær som hadde kuppet makten. Opprøret som startet i 2011 besto i stor grad av ikke-militære med improvisert og flat struktur. Lufthjelp fra NATO for å «beskytte sivile» giorde det mulig for grupper fra ulikt hold å erobre territorium, olje- og gassfelt og andre verdifulle landområder, uten noe klart hierarki mellom seg. Hovedstaden Tripoli kunne falle uten at et militært kommandosystem på bakken var nødvendig. Problemet oppsto i neste ledd. Da forhandlingene om det nye Libya kom, var det 
ikke klart hvem som skulle besørge og kontrollere sikkerhetsstrukturen. Ingen som hadde kjempet gav seg uten kamp! Etter hvert var det fritt fram for alle tenkelige voldsentreprenører. Vestlig intervensjon etterlot Libya i væpnede gruppers vold.

Syria hadde derimot et fullt operativt sikkerhetssystem, ansett som verdens 11 . sterkeste konvensjonelle militære i 2010, noe som delvis var et utslag av Russlands fornyede interesse. Fire år med uthalingskrig har brakt det syriske sikkerhetsapparatet til randen av kollaps. Over 30000 unge menn fra minoriteten alevitter (ca. 10\% av befolkningen) har ofret livet for å holde regimet ved makten. Estimater fra de som fortsatt teller, er at 470000 mennesker er drept i krigen så langt (Syrian Centre for Policy Reporting 2015). Da Russland trådte inn i Syria for fullt høsten 2015 etter en sommer hvor Tyrkia og Saudi Arabia hadde skrudd opp presset mot regimet betydelig, var det for å redde stumpene av det syriske stats- og sikkerhetsapparatet før det desintegrerte fullstendig. På dette tidspunktet var det flere enn Moskva som mente at dette var en god idé.

Vestlige intervensjoner har lagt sikkerhetsapparatene i disse landene i ruiner. De var viktige bestanddeler for regimenes maktbase. De var også instrumenter for trusler mot vestlige land, og ble benyttet til undertrykkelse av (deler av) egen befolkning. De samme sikkerhetsapparatene tjente imidlertid også som garantister for sikkerhet og orden for egen befolkning, og som voktere av migranter på vei mot Vesten. Vestlige land har ikke maktet å sørge for at pålitelige og legitime sikkerhetsapparater ble gjenetablert $\mathrm{i}$ forlengelsen av intervensjonene. Dermed har vestlige intervensjoner $\mathrm{i}$ praksis ødelagt deler av Europas «førstelinjeforsvar» mot migranter i sør og sør-øst.

\section{De frie nasjoners byrde}

Det tredje argumentet for en sammenheng mellom flyktningkrisen og vestlige intervensjoner ligger $\mathrm{i}$ håpet som brast, i avgrunnen mellom fagre ord og lovnader om nye samfunnsmodeller som har fulgt med intervensjonene på den ene siden og hva som faktisk har blitt levert på den andre. For edle motiver og store vyer har det ikke skortet på. Samtlige vestlige intervensjoner i Midtøsten siden 2001 har foregått under demokrati- og menneskerettighetenes bannere.

Mot slutten av 1980-tallet pågikk en demokratisk oppmykning i flere arabiske land. Etter den kalde krigens slutt gikk imidlertid demokratiseringen i stå. Da det muslimske brorskap lå an til å vinne parlamentsvalget i Algerie i 1992, svarte den regjerende eliten med å kuppe makten med Frankrikes hjelp. Anslagsvis 150000 menneskeliv gikk tapt i den svært brutale borgerkrigen som fulgte, noe som la en klar demper på demokratiseringsiveren i andre arabiske land. Mens resten av verdens diktatorer trådte av, strammet de autoritære regimene i Midtøsten grepet til. Dette gav fint lite demokrati. Derimot gav det rimelig godt tilfang til jihadistbevegelsen til Bin Laden og andre islamistiske grupperinger.

Utover på 1990-tallet arbeidet Europa for å styrke demokratiske krefter i Midtøsten. Barcelona-prosessen skulle skape marked og vekst på sørsiden av Middelhavet, øke eksport av varer fra Europa, og minske tilsiget av mennesker nordover. Det langsiktige målet var demokrati. Man forsøkte å styrke sivilsamfunnet, embetsverk og Ngo-er, krefter 
som senere ble fundamentet for den arabiske våren i 2011. Ett dilemma var at når vestlig innblanding ble for tydelig, ble våre støttespillere delegitimert på hjemmebane, det være seg politiske organisasjoner eller grasrotbevegelser. Et annet var at det særlig var brorskapsbevegelsene - det islamske alternativet - som fikk vind i seilene i perioder med demokratisk oppmykning. Her skimtet europeere konturene av «én mann, én stemme, én gang». Frykten var at islamister ville benytte valg for å komme seg til makten, men deretter avskaffe valgordningen for andre, og altså basere seg på en helt annen type legitimitet enn hva Europa søkte å fremme rundt Middelhavet.

Amerikanske miløøer syslet også med ambisjoner om demokratisering av Midtøsten. Mest offensivt var det neo-konservative Project for a New American Century som i 1999 formulerte svært vidtrekkende visjoner for Midtøsten. Dette var krefter som kom tett på makten da George W. Bush tok over i 2000. Bush selv fant inspirasjon hos den sovjetiske dissidenten og israeleren Natan Sharansky, som etterlyste innsats for å frelse Midtøsten fra autoritarisme. Etter 2001 skulle denne bukken tas ved hornene. Demokrati ble et instrument for å hindre internasional terrorisme snarere enn et mål i seg selv.

I Afghanistan skulle valg frigjøre landet fra hundrevis av år i klanenes klamme favntak. Men ikke alle fikk være med inn i den nye tid. Amerikanerne var klokkeklare på hvilke krefter som var uønsket. Dette var afghansk folkestyre underlagt amerikansk sensur. Vi tumlet inn i Afghanistan for å fjerne noen fiender, og endte opp med å skulle lage folkestyre, delvis uten folket, alliert med krigsherrer, men uten våre venners venner, som var våre fiender. Et ambisiøst, men ensomt foretagende.

Invasjonen i Irak var derimot den best planlagte intervensjonen i verdenshistorien. Dette hadde USA forberedt helt siden 1991. Men planene ble igjen hjemme. Vesten skjøv den tidligere makteliten, sunni-minoriteten ut i kulden, vi lot sjiaflertallet ta makten, men nektet å samarbeid med deres regionale allierte, og valgte heller allianse med den kurdiske minoriteten. Den nye valgmodellen fremmet sekterisk tilhørighet, med kurdisk minoritetsveto. Diktatur erstattet vi med «sekterisk demokratur». Det ble begynnelsen på slutten for Irak.

Men naboland tok hintet etter 2003. Egypt og land i Nord-Afrika og Gulfen åpnet for mer valg. I valgskredet som fulgte i de neste årene i Irak, Egypt, Jordan, Marokko og Jemen gjorde partier knyttet til det muslimske brorskap store innhugg i den del av kaken som ble gjort tilgjengelig for dem. Valget som fikk størst oppmerksomhet var det reelt demokratiske valget hos palestinerne, finansiert og organisert av Europa for å skaffe én partner for fred til Israel. Valget endte med seier for brorskapspartiet Hamas. Europa grøsset, og rygget. Det ble stadig mer krevende å skulle engasjere seg i demokratiprosesser som produserte det Europa i stor grad anså som anti-demokratiske og endog farlige krefter. Striden omkring Muhammed-karikaturene, som «brøt ut» i kjølvannet av valgskredet illustrerte det hele. Europa ble ytterligere skeptisk til hvilke krefter som fantes under overflaten da flagg fra stater som Danmark og Norge brant over hele Midtøsten. Karikaturstriden var samtidig en «hjelpsom påminnelse» til muslimer om hva vestlig demokrati og menneskerettigheter handlet om - frihet til Profetbespottelse!

USA hadde stått fremst som forkjemper for demokrati gjennom våpenmakt, men inntok etter hvert en svært pragmatisk holdning. Irak var på vei inn i borgerkrig, 
Taliban var på offensiven i Afghanistan, tiden var inne for smertefulle kompromisser, og ambisjonene om demokrati ble betydelig dempet.

Europas mer lavmælte innsats for demokratisering i våre nærområdene var også $i$ ferd med å bli vel krevende. Det var komplisert å drive dette utenfra. Arabiske utviklingsrapporter etter 2002 gav nedslående diagnoser og enda grellere prognoser. Derfor var det stor lettelse som bredte seg i europeiske land da den arabiske våren kom i 2011. Her var beviset for at det fantes kraft og miljøer på innsiden av disse statene som selv kunne ta hånd om egen skjebne. Europa var for! Da libyere ba om hjelp for å kaste åket av, stilte Europa villig med kuler og krutt for å gjøre kort prosess.

Problemene sto imidlertid i kø. Dersom utenforstående makter, gamle koloniherrer eller USA blandet seg direkte inn, risikerte man å delegitimere prosessen. Ble den påtvunget utenfra, ville den også måtte holdes av utenforstående. Dette skulle araberlandene eie selv. Handlingsrommet var derfor begrenset. I tillegg var det jo brorskapsbevegelsen som tjente mest på våren. Mer foruroligende var at den «dype staten», altså samfunnets reelle maktstrukturer i disse landene mobiliserte for fullt. Stater som Saudi Arabia og Emiratene, med sterk egeninteresse i å holde våren på en armlengdes avstand, kastet seg inn i maktkampen for å vippe dette tilbake i reaksjonære krefters sikre favntak i land som Egypt, Libya og Syria. Land som Tyrkia og Qatar hadde strategiske interesser i at reelle valg (og dermed brorskapet) skulle vinne frem, og la sine egg i den andre kurven. Dette var maktkamp mellom regionens krefter, hvor USA og Europa etter hvert ble henvist til tilskuerplass. I Syria sviktet både Vestens evne og vilje til å ta prosjektet i havn. Prisen ble for høy.

Det dramatiske klimaks kom i 2013. Presidenten i Egypt, brorskapsmannen Mursi, ble fjernet av militæret, og da Egypts militære makthavere massakrerte rundt 1000 ubevæpnede brorskapsmedlemmer i Raba' i august, var det særlig Europas reaksjon som sjokkerte. Hadde Europa gitt opp hele prosjektet? Kjemivåpenangrepet med rundt 1000 døde i Damaskus en uke senere endte verken med Libya-prosess i Sikkerhetsrådet eller med at USA kom til unnsetning. I 2013 døde den arabiske våren, europeerne gav opp og amerikanerne gikk sammen med russerne for å avvæpne Syria. Regionen var overlatt til seg selv.

Og det var altså i 2013 at flyktningkrisen i Syria gikk fra krise til katastrofe. Ved inngangen til 2013 var FNs høykommissær for flyktningers (grove) estimater at det var 2745522 fordrevne syrere. Ett år senere var tallet 8989124 (FNs Høykommissær for flyktninger 2011 og 2013). Det tilsvarer et snitt på 9500 nye fordrevne hver dag gjennom hele 2013. Først i 2015 nådde denne bølgen Europa med full kraft.

Effektene av regimeskifte og den forrykkelse av maktforhold på lokalt, nasjonalt og regionalt plan slike skifter alltid innebærer har blitt ytterst stemoderlig behandlet av vestlige land. Etter hvert som prisen steg og tilbaketrekningsdatoen ubønnhørlig har meldt sin ankomst, har vestlig ideologisk hardnakkethet blitt byttet ut med pragmatisk realisme. Vesten har holdt fanen høyt mot det absolutte onde frem til vestlige land kommer i tilbaketrekningsmodus. Da er pakt med fordums evige fiender derimot å anse som et nødvendig onde. 
Anti-terrorsystemene som regimene i Midtøsten bygget opp etter 2001 for å støtte vestlig innsats mot terrorisme (samt å tjene som hendig instrument i kampen mot egne rivaler) har etter 2013 blitt vendt med full kraft mot kreftene som søkte å endre regimene under den arabiske våren, som i Egypt, hvor antallet politiske fanger antas å være femsifret. Vestlige land har abdisert, og forholder seg avventende.

Den europeiske mission civilisatrice søkte demokrati og menneskerettigheter for naboland i sør, også av egeninteresser. Europa har imidlertid i forbausende liten grad maktet å stå ved sine idealer og visjoner i møte med en brutal virkelighet hvor kampen mellom ulike samfunnskrefter er nådeløs. Dette er ikke vår kamp, vi har få gode virkemidler, og det er uklart om resultatet vil tjene våre interesser. Dessuten har vi mer enn nok med våre egne problemer, ellers takk! Fra sørsiden fremstår det som om Europa har forlatt alle visjoner og håp for land i randsonen. Budskapet er klokkeklart. Ønsker du demokrati, menneskerettigheter, frihet eller likhet (eller arbeid og verdighet) for dine barn, er det kun én ting å gjøre. Pakk sekken. Dra nord.

\section{The unbearable lightness of fleeing?}

Men krig kom jo verken til Afghanistan eller Irak som følge av vestlige intervensjoner. Det var Iran-Irak-krigen, initiert av Irak i 1981 som var starten på elendigheten i Irak. I Afghanistan var det derimot Sovjetunionens inntog i 1979 som var utgangspunktet. Disse krigene var åpenbart ikke løsrevet fra hva vestlige land foretok seg, men det er krevende å skulle forklare effektene med henvisning til «Vestens politikk» alene. Argumenter om at det er lange historiske linjer som virker her, og at vestlig intervensjon kun har vært mindre, dog relativt mislykkede, intermessoer har klart noe for seg. Både Afghanistan og Irak produserte flyktninger i flere tiår før vestlig intervensjon. Faktisk snudde trenden i noen år like etter intervensjonene, en effekt som holdt i 4 år for Irak og nærmere 10 år for Afghanistan.

For om måten USA par(t)erte Irak det første året etter invasjonen kan forklare mye av påfølgende elendighet i Irak og til dels Syria, var det like fullt militær tilbaketrekning fra Irak i 2011 som brakte landet tilbake på randen av borgerkrig, og tilrettela for etableringen av ISIL i 2014. Det var også vestlig tilbaketrekning fra Afghanistan som sammenfalt med hevet konfliktnivå i 2015 (over 11000 skadde og døde) og økt flyktningestrøm mot Europa. Fellesnevneren for Afghanistan og Irak er at det rakner først når Vesten trekker seg ut. Tilbaketrekning foranlediget exodus.

Libya og Syria er en annen historie. Her har vestlige intervensjoner bidradd til å fjerne eller svekke regimer i Europas randsone som har vært sentrale knutepunkt i den internasjonale flyktningeinfrastrukturen. Dette var stater som hadde opplevd uro i naboland, men med regimer som styrte med hård hånd. Libya under Gaddafi hadde avtaler med europeiske land om «forvaltning» av migrasjonspresset fra sør (Bilateral avtale med Italia 2009, Sammarbeidsavtale med EU 2010), som riktignok Europas menneskerettighetsdomstol senere har ansett som brudd med den europeiske menneskerettighetskonvensjonen (Hirsi Jama 2012). Det var i visse henseender begrensningen i inngripen i Libya som la til rette for kaos, og den påfølgende mangelen på et sikkerhetsapparat som har gjort Libya til naturlig hovedfartsåre til Europa de siste 
årene. Likeledes var det mangelen på vestlig inngripen i Syria i 2013 som brakte konflikten over i en massiv stedfortrederkrig, og som virkelig fikk fart i det syriske exodus. Syria var i 2011 på tredje plass i verden som vertsnasjon for flyktninger. Tre år senere, ved utgangen av 2013, var rundt $20 \%$ av verdens fordrevne syrere. Vestlige lands politikk ovenfor Syria har klart medvirket til å gjøre Syria om fra en av verdens fremste tilfluktsteder for flyktninger fra andre land, til å bli den staten i verden som flest flykter fra.

Hasardiøse og halvhjertede demokratiseringsforsøk i kjølvannet av vestlige intervensjoner har strandet. Innsatsen har vært grunn, for ambisiøs eller for dårlig. I Irak og Afghanistan var målsetningene latterlig høye og innsatsen tilfeldig. I Libya og Syria har innsatsen være nølende, reservert og selektiv. Fra Washingtons side ligger det globale, realpolitiske vurderinger bak en mer tilbaketrukket rolle i Libya og Syria. Fra et europeisk perspektiv burde det hele imidlertid fortone seg annerledes. Afghanistan er periferi for Europa. Det kan verken sies om middelhavslandene Libya eller Syria, og i forlengelsen Irak. For om Europa kan svikte sine idealer, er geografi like fullt en gitt størrelse. Den gir et skjebnefellesskap med utviklingen i våre naboland i sør som Europa altså ikke kan løpe fra.

Og i dette perspektivet fremstår Europas haltende engasjement i kjølvannet av intervensjon og innblanding i Libya og Syria som helt uforståelig. Europa medvirket til at to stater som var instrumentelle i å holde flyktninge- og migrasjonsstrømmen mot Europa i sjakk, ble kastet ut i kaos. Vi hadde høye ambisjoner, men fulgte ikke opp, tilsynelatende i den tro at effektene ikke angikk oss. Først da Tyrkia åpnet slusene mot Europa høsten 2015 ble Europa tvunget til å ta konsekvensene av sitt naboskap.

Vestlige intervensjoner har levert i form av å uskadeliggjøre fiendtlige regimer som potensielt kunne benyttet masseødeleggelsesvåpen. Utilsiktede effekter har imidlertid vært at statsapparatene ikke lenger er i stand til å garantere sikkerhet for folk flest, og at politiske strukturer etablert i kjølvannet er demokrati kun i form og ikke i norm. I dag er det ikke-statlige grupper som i stor grad råder grunnen i disse landene. Det representerer en mindre fare for Vesten, men en betydelig større fare for befolkningen som lever i disse landene. Mens Vestens intervensjoner har gjort oss tryggere, har den gjort befolkningen i disse landene betydelig mer utrygg. Vi slipper kanskje fiendtlige regimer i sør, men må nå forholde oss til den avledede effekten at innbyggere som skulle befris lokalt, etter hvert ser få andre utveier til trygghet, frihet og en fremtid enn å søke tilflukt hos oss i Europa.

\section{Litteraturliste}

Bergen, Peter (2006) The Osama Bin Laden I Know: An Oral History of the al-Qa'ida Leader. New York: Free Press.

Bilateral avtale mellom Italia og Libya (2009), tilleggsprotokoll av 4. februar 2009.

Bolton, John R. (2002) Beyond the Axis of Evil: Additional Threats from Weapons of Mass Destruction. Tale 6. Mai hos Heritage Foundation. Tilgjengelig på http://www.heritage.org/research/lecture/beyond-the-axis-of-evil

Bush, George W. (2002) State of the Union Address, 29. Januar, 2002. Tilgjengelig på https://web.archive.org/ web/20090502151928/http://georgewbush-whitehouse.archives.gov/news/releases/2002/01/20020129-11. html 
Di Bartolomeo, Anna, Tamirace, Fakhoury \& Delphine Perrin (2011) «Consortium for Applied Research on International Migration - Migration Profile, Libya» Robert Schuman Institute for Advanced Studies, European Univeristy Institute, juni.

Dodge, Toby (2005) «Iraq's Future: The Aftermath of Regime Change», Adelphi Paper 372, International Institute for Strategic Studies, Routledge.

Eurostat (2016) «Asylum in the EU Member States. Record number of over 1.2 million first time asylum seekers registered in 2015 - Syrians, Afghans and Iraqis: top citizenships». Eurostat pressemelding 44/2016, 4. mars, tilgjengelig på http://ec.europa.eu/eurostat/documents/2995521/7203832/3-04032016AP-EN.pdf/

FNs Høykommissær for flyktninger (2011) og (2013) «Yearbook, global forced displacement trends.» Tilgjenglig på http://www.unhcr.org/pages/49c3646c4d6.html

ICG (2003) International Crisis Group Report «Iraq: Building a New Security Structrue», ICG Middle East Report N. 20, Bagdad/Brussels, 23 desember, s 13.

Hirsi Jama v. Italia, den europeiske menneskerettighetsdomstol, Grand Chamber 27765/09, 23. Februar 2012. Tilgjengelig på http://hudoc.echr.coe.int/app/conversion/pdf/?library=ECHR\&id=001-109231\&filename= 001-109231.pdf

Khadduri, Majid \& Edmond Ghareeb (1997) War in the Gulf, 1990-91; The Iraq-Kuwait Conflict and its Implications. New York: Oxford University Press.

NYT (2014) US Intelligence Documents on Chemical Weapons Found in Iraq, frigitt under amerikansk innsynslovgivning, 14. oktober. Tilgjengelig på http:/www.nytimes.com/interactive/2014/10/14/world/ middleeast/us-intelligence-documents-on-chemical-weapons-found-in-iraq.html

Organisation for the Prohibition of Chemical Weapons (2014) «Libya Completes Destruction of its Category 1 Chemical Weapons,» OPCW News E Publications, 4. Februar. Tilgjengelig på www.opcw.org

Ross, Dennis (2004) The Missing Peace: The Inside Story of the Fight for Middle East Peace, Washington Institute for Near East Policy. New York: Farrar, Straus and Giroux.

Samarbeidsavtale mellom EU og Libya om stans i ulovlig migrasjon, 4. oktober 2010.

Singer, Peter (2007) Can't Win With 'Em, Can't Go To War Without 'Em: Private Military Contractors and Counterinsurgency, Brookings Policy Paper, No 4, september 2007. Tilgjengelig på http://www.brookings. edu/ /media/research/files/papers/2007/9/27militarycontractors/0927militarycontractors.pdf

Syrian Centre for Policy Reporting (2015) «Confronting Fragmentation - Impact of Syrian Crisis Report» kvartalsrapport 2015, 61. Tilgjenglig på http://scpr-syria.org/publications/confronting-fragmentation/ 